Environmental Technology

April 2008, Volume 29, Issue 4, pages 451 - 461

http://dx.doi.org/10.1080/09593330801983912

(c) 2008 Taylor \& Francis Group
Archimer http://www.ifremer.fr/docelec/ Archive Institutionnelle de l'Ifremer

\title{
Recovery of valuable soluble compounds from washing waters generated during small fatty pelagic surimi processing by membrane processes
}

\author{
J. Dumay ${ }^{a,}{ }^{\star}$, S. Radier ${ }^{a}$, G. Barnathan ${ }^{b}$, J. P. Berge ${ }^{a,{ }^{*}},{ }^{*}$ P. Jaouen ${ }^{c}$
}

\author{
a IFREMER, Nantes Atlantique Universités, BP 21105, F 44311 Nantes, France \\ ${ }^{b}$ SMAB, Nantes Atlantique Universités, France \\ ${ }^{c}$ GEPEA, UMR-CNRS 6144, CRTT, Nantes Atlantique Universités, Saint-Nazaire, France

\begin{abstract}
*: Corresponding author : J. Dumay, email address : justine.dumay@gmail.com, J.P. Bergé, email address : Jean.Pascal.Berge@ifremer.fr
\end{abstract}

\begin{abstract}
:
This work focuses on the treatment of washing waters coming from surimi manufacturing using ultrafiltration technology at a laboratory scale. Four membrane materials (poly-ether sulfone, polyacrilonytrile, poly vinylidene fluoride and regenerated cellulose) and 5 Molecular Weight Cut-Off (from 3 to $100 \mathrm{kDa}$ ) have been studied at bench laboratory scale using the pilot Rayflow ${ }^{\circledR} 100$, commercialised by Rhodia Orelis. The investigation deals with the ability for membranes to offer a high retention of biochemical compounds (proteins and lipids). Results obtained during adsorption tests showed that the regenerated cellulose material seems to be the most appropriate with regards to pore size reduction due to the protein-adsorption. During the ultrafiltration of the washing water, the regenerated cellulose material leads to the best results, followed by the polyacrylonitrile and polyvinylidene fluoride materials. Poor results were obtained with poly-ether sulfone membrane. Compared to the other materials, the regenerated cellulose is the easiest to regenerate, with minimal cleaning water and no chemical treatment necessary. Biochemical characterization of the fractions generated during the ultrafiltration with the polyacrilonytrile, poly vinylidene fluoride and regenerated cellulose membranes showed that all the membranes provided a high recovery rate of the lipids and proteins. The $10 \mathrm{kDa}$ regenerated cellulose membrane had the highest performance and was further evaluated. With such a treatment, the chemical oxygen demand was reduced by $75 \%$. By performing hydrolysis followed by a centrifugation, biochemical composition of the sludge and liquid fraction were modified, producing an insoluble fraction containing fats and few proteins and a soluble fraction containing proteins and few fats. The sludge, initially insoluble, was mainly solubilized during hydrolysis, and lipids and peptides were concentrated by ultrafiltration.
\end{abstract}

Keywords: Ultrafiltration; enzymatic hydrolysis; surimi wastewater; regenerated cellulose; fish oil

\section{INTRODUCTION}

Oceans possess diversified and exploited food resources (seaweeds, crustaceans, molluscs, fishes). Globally, according to the FAO, more than 130 millions tons of fish are currently caught or produced from fish farming [1]. Sea products can be eaten fresh, frozen, dried or transformed. One of the major fish transformations consists to obtain a washed fish pulp with added cryoprotectors: the "surimi base". Hence, this transformation confers to the product a higher conservation and functional protein stability during frozen storage. Surimi manufacturing is generally realized with Alaska pollack or blue whiting, but a decade ago, the use of small fatty pelagic fish, such as sardine or horse mackerel, has been investigated to produce surimi [2]. While the transformation process adaptation has been studied for few years [3], 
environmental guidelines encourage industrialists to consider wastes generated during the manufacturing. Solid by-products represent from 30 to $60 \%$ of the whole fish and, in 2005, the French by-product production was 150,000 tons [4]. Liquid by-products could also been obtained, especially during fish processing [5]. Concerning surimi manufacturing, liquid by-products are mainly represented by the washing waters. Indeed, surimi is a concentrate of fish myofibrillar proteins obtained by successive washings of minced fish to remove blood, lipids, enzymes and sarcoplasmic proteins [2]. Thus, high water volumes are used during surimi transformation and resulting washing waters possess an important protein load. A recent review [6] indicates that the wastewater coming from surimi processing contains approximately $2-5$ g.L.-1 of water soluble proteins. The wastewater from the first washing/rinsing by fresh water in surimi production contains the highest concentrations of proteins, non-protein nitrogen, fat and ash. So, it is essential to find out new up-grading ways for those by-products, with environmentally sound procedures requiring low energy consumption [5]. Membrane techniques, which are less expensive that thermal treatments, could be a solution to upgrade the fractions [6]. These procedures allow the reduction of the polluting load by means of the retention of the compounds by the membrane. The outstanding advantages of these processes are the potential good quality of the permeate which can be recycled into the plant, besides the possibility of simultaneously recover and concentrate the proteins. Indeed, proteins obtained from surimi washing water ultrafiltration or microfiltration have shown similar functional properties than those recovered in the surimi paste [7]. Another important advantage of pressure-driven membrane processes is that they are particularly suitable for the concentration and purification of sensitive biological high addedvalue substances under mild conditions without using heat or chemical [8]. Proteases for example can be recovered from surimi washing waters using ultrafiltration (with a 30 or $50 \mathrm{kDa}$ poly ether sulfone membrane). Hence, compounds of interest have been obtained, reducing simultaneously the environmental pollution $[9,10]$. Membrane treatment of washing waters has been studied since the 80 's and many publications report their use (or potential use) in fish processing industries [8]. The principal challenge of this research field is to find out a suitable material for effective protein retention with low fouling phenomenon, good regenerability, high durability and low processing costs. Studies must also take into account the specificity of fish species used to produce surimi.

The objective of the paper is to this study at the laboratory scale the recovery of valuable compounds (proteins and lipids) from sardine surimi washing waters by ultrafiltration with a simultaneous reducing of the polluting load of effluents. Four membrane materials: poly-ether sulfone (PES), polyacrylonitrile (PAN), polyvinylidene fluoride (PVDF) and regenerated cellulose (RC) with five molecular weight cut-off (MWCO) 3, 10, 40, 50 and $100 \mathrm{kDa}$ were tested. Membranes were characterized for their adsorption, permeation flux, regenerability and lipids and proteins retentions. The most effective membrane was then selected for further tests on ultrafiltration of the surimi washing waters in a concentration mode.

In order to up-grade most of the by-products from effluents, the solid fraction extracted from washing waters following centrifugation was hydrolyzed using proteases. Indeed, it has been shown that the proteolysis on fish matter can solubilize a large part of the insoluble fraction [11, 12]. Thus, the resulting liquid fraction can then be treated using ultrafiltration following the same process and generated peptides and up-gradable lipids. 


\section{MATERIAL AND METHODS}

\section{Surimi manufacturing process}

The aim of the transformation process is to obtain a stable product from fish mince. Main steps of such a process are presented in Figure 1.

Sardines (Sardina pilchardus) from Atlantic North East fishing area were harvested from Les Pêcheries Océanes (Nantes, France). Fish were quickly beheaded and eviscerated in order to prevent the intestinal proteases action on muscular proteins and the viscera micro-organisms alteration. The obtained flesh was then pressed continuously inside a perforated cylinder. This step contributes to the flesh grinding and to separate mince from skin and bones (which were then eliminated). The resulting mince was then successively washed and dewatered with chilled tap water, constituting the key steps of the surimi manufacturing process. Their main goal is to eliminate non desirable components, such as blood, low molecular weight soluble compounds, sarcoplasmic proteins, enzymes, lipids and some non proteinic nitrogenous compounds and to concentrate the myofibrillar proteins (actin and myosin), which possess gelling properties. The number of washing steps and water volume required vary according to fish species, fish freshness, the transformation line used and the desired surimi quality [3]. In this study, two washing steps were performed (corresponding to the washing waters fractions W1 and W2). Mince was refined (refined mince) in a refiner to remove undesirable particles, such as bones and connective tissues. Then it was dewatered in a centrifuge decanter until a paste was obtained. This paste was a protein concentrate with $82-85 \%(\mathrm{w} / \mathrm{w})$.

\section{Fractioning washing waters for ultrafiltration}

The wastewater obtained during the surimi manufacturing was then treated according to the scheme represented in Figure 2. Jaouen and Quéméneur [13] showed that processing of surimi washing waters by ultrafiltration without pre-treatment was not practical. Huang and Morrissey [14] characterized the filtration fouling of surimi washing waters. They determined that fouling occurred initially as a result of pore blocking. In this study, the raw wastewaters were first decanted, and then centrifuged at 4,000 g for $20 \mathrm{~min}$ at room temperature to obtain an aqueous fraction (A2) and sludge (S2). The resulting aqueous fraction was then ultrafiltered while the first sludge (S1) obtained after the decantation was hydrolysed with proteases (see next) before the ultrafiltration run. The conditions for ultrafiltration of A2 were studied.

\section{Ultrafiltration pilot}

All the experiments employed a flat-sheet organic membrane module, with a surface of $2 \times 100 \mathrm{~cm}^{2}$ which could support a pressure of 3 bars (Rayflow ${ }^{\circledR} 100$, Rhodia Orelis, Miribel-France). The characteristics of this kind of pilot are given in Table 1 . The operationg temperature was adjusted with the use of a cooling circulator bath (Haake F3, Fisons, Germany), which had been set to the appropriate temperature $\left(15^{\circ} \mathrm{C}\right)$. Pump's caractreristics were as follow: Micropump Inc. Vancouver USA, Mod 806, $0.55 \mathrm{Kw}$, variable rotating speed $(0-600 \mathrm{l} / \mathrm{h})$ equipped with Head mod. 221 (gears). 


\section{Membranes}

The main characteristics of each studied membrane (with various material and molecular weight cut-off (MWCO)) are reported in Table 2.

Membrane materials have been chosen to cover a large range in (i) surface charge: for example PVDF and PES are neutral, while PAN can be neutral (3038), charged + (3050), or charged - (3042) and in (ii) hydrophobicity (RC and PAN more hydrophilic, PES and PVDF more hydrophobic).

\section{Membrane cleaning process}

An ultra-pure water flux measurement was systematically conducted before and after each experiment or cleaning process in order to make sure that the membrane recovery is satisfactory. The water flux was measured at $15^{\circ} \mathrm{C}$ with a pressure of $1 \mathrm{bar}$.

The chemical cleaning process was performed at 0.5 bar and $50^{\circ} \mathrm{C}$. This process was divided into two steps: an alkali cleaning, using sodium hydroxide ( $\left.\mathrm{NaOH}, 0.4 \mathrm{~g} . \mathrm{L}^{-1}\right)$ at $40^{\circ} \mathrm{C}$ for $20 \mathrm{~min}$ and then an acidic cleaning using nitric acid $\left(\mathrm{HNO}_{3}, 1\right.$ g.L $\left.\mathrm{L}^{-1}\right)$ at $40^{\circ} \mathrm{C}$ for $20 \mathrm{~min}$. A rinsing step with deionised water was conducted after each step.

The aforementioned process was used for the PAN, PES and PVDF membranes, whereas for the $\mathrm{RC}$ membrane, a simple water rinse was sufficient to recover its initial permeability.

\section{Adsorption tests on different membrane materials and MWCO}

After measuring the reference water flux ( $\left.\mathrm{J}_{\mathrm{o}}\right)$ of new membranes, membranes were introduced for a static contact $\left(20 \mathrm{~h}\right.$ at $\left.15^{\circ} \mathrm{C}\right)$ in a $500 \mathrm{~mL}$ vessel with the water $\mathrm{A} 2$. The membrane was then inserted in the ultrafiltration module and a deionised water flux $\left(\mathrm{J}_{\mathrm{a}}\right)$ was measured at $15^{\circ} \mathrm{C}$ with a pressure of 1 bar. Therefore, a comparison of flux before $\left(\mathrm{J}_{\mathrm{o}}\right)$ and after $\left(\mathrm{J}_{\mathrm{a}}\right)$ the adsorption could be done.

\section{Solubilisation of the sludge S1 using enzymatic hydrolysis}

The S1 fraction recovered during the separation phase (Figure 2) was significant. So, in order to up-grade most of the surimi manufacturing by-products coming from effluents, this fraction has been hydrolysed for a further ultrafiltration treatment.

In a thermostatic 2L vessel glass, around $700 \mathrm{~g}$ of sludge and $700 \mathrm{~mL}$ of water were homogenized. The system was continuously stirred until the temperature has reached $60^{\circ} \mathrm{C}$ and the $\mathrm{pH}$ a value of 6.5. Due to its classical use in the protein hydrolysate manufacturing and its relatively low cost, papaïn (also called Protease V100) was used for the hydrolysis. Enzyme (2\%) and cystein $(0.025 \%)$ were added to the system and the hydrolysis was conducted controlling the $\mathrm{pH}$ (adding $\mathrm{NaOH} 40$ g.L-1 ) at room temperature for 2 h. The enzyme was then inactivated by heating and the hydrolysate was centrifuged as previously described. The resulting supernatant, the A3 fraction, was then ultrafiltered according to the previously described conditions.

\section{Biochemical analyses}

\section{Water content}

Dry matter content was estimated gravimetrically after heating overnight at $105^{\circ} \mathrm{C}$. 


\section{Lipid content}

Lipid extraction was carried out according to the method described by Folch [15]. About $1 \mathrm{~g}$ (exactly measured) of dry sample was homogenized in $4 \mathrm{~mL}$ distilled water. Methanol (Technical grade, Carlo Erba, France) was added to the mixture (ratio mixture/methanol: 3/20, weight/volume $(w / v))$. Samples were then stirred for $30 \mathrm{~min}$ before adding chloroform (Technical grade, Carlo Erba, France) (ratio mixture/chloroform: 3/40, w/v). The system was stirred for $30 \mathrm{~min}$ before filtration and addition of 0.2 volume of water with $0.9 \% \mathrm{NaCl}$. After $15 \mathrm{~h}$ decantation at $+4^{\circ} \mathrm{C}$ in darkness, lipids were recovered in the organic phase. Lipid extracts were dried under vacuum in a rotary evaporator (temperature $<35^{\circ} \mathrm{C}$ for lipid conservation). Lipids were weighed and results expressed as $\mathrm{g}$ of lipid per $g$ of dry matter. Lipid extracts were kept in $10 \mathrm{~mL}$ chloroform and stored at $-80^{\circ} \mathrm{C}$.

\section{Protein content}

Crude protein content $(\mathrm{N} \times 6.25)$ was estimated in the raw material and the aqueous phase from hydrolysis and determined colorimetrically after Kjeldhal digestion using the method described by Crooke et al. [16]. 


\section{RESULTS AND DISCUSSION}

\section{Membrane selection}

An efficient membrane should fulfil simultaneously three conditions: high and stable flux, high selectivity according to the objective of the filtration and good regenerability.

The first step of this study consists in determining, among those previously described, the membrane with the best performances. This experimental work is based upon several adsorption tests [17] and ultrafiltration steps of the washing waters A2 (Figure 2).

\section{Solvent flux, pore size reduction}

With a pure solvent, such as deionised water, the permeate flux ( $\left.\mathrm{J}_{\mathrm{o}}\right)$ generally varies linearly with the transmembrane pressure.

When comparing pores to straight cylinders pathways, the Poiseuille relation (i) allows one to express the permeation flux according to the solvent and the membrane (especially pore size) characteristics and to the ultrafiltration conditions.

After a simple static contact between the membrane and the solution to be ultrafiltered during a determined time and in a given temperature, the permeate flux decreases from $\mathrm{J}_{\mathrm{o}}$ to $\mathrm{J}_{\mathrm{a}}$ consecutively to the pore size reduction $\Delta \mathrm{r}$ due to the adsorption phenomenon. Indeed, pores are covered of a layer of adsorbed solutes with a thickness considered as constant $\Delta \mathrm{r}$ :

$$
\mathrm{J}_{\mathrm{a}}=(\mathrm{N} \cdot \pi)\left(\frac{(\mathrm{r}-\Delta \mathrm{r})^{4}}{8 \eta}\right)\left(\frac{\mathrm{TMP}}{\Delta \mathrm{x}}\right)
$$

Where $\mathrm{J}_{\mathrm{a}}$ : solvent (deionised water) flux after adsorption $\left(\mathrm{m}^{3} \cdot \mathrm{m}^{2} \cdot \mathrm{s}^{-1}\right)$

$\mathrm{N}$ : number of pores per unit surface $\left(\mathrm{m}^{-2}\right)$

$\mathrm{r}$ : mean pore size rayon $(\mathrm{m})$

$\eta$ : dynamic viscosity of solvent (Pa.s)

TMP: transmembrane pressure $(\mathrm{Pa})$

$\Delta \mathrm{x}:$ membrane thickness $(\mathrm{m})$

$\Delta \mathrm{r}$ : adsorbed layer thickness (m)

In the case of protein solutions, the adsorption phenomenon causes a decrease of water flux, which could be important, and consequently increases significantly the hydraulic resistance of the porous medium.

Therefore, the initial choice of the membrane is essential due to these characteristic modifications and their influence on the operation selectivity. Moreover, the further cleaning step for the membrane regeneration (generally using chemicals) will also be facilitated (less time and solvent consuming, low temperature) while the interactions solutes/membrane are minimized.

With a simple measure of Jo and $\mathrm{J}_{\mathrm{a}}$, Zeman [18] had proposed to quantify the adsorption effect using a Poiseuille-derived formula. The pore size reduction is expressed as follow: 


$$
\frac{\Delta \mathrm{r}}{\mathrm{r}}=1-\left(\frac{\mathrm{J}_{\mathrm{a}}}{\mathrm{J}_{\mathrm{o}}}\right)^{0.25}
$$

Results obtained for an adsorption test in static conditions (without pressure and permeation) $20 \mathrm{~h}$ long at $15^{\circ} \mathrm{C}$ are reported in Table 3 .

The higher water flux before adsorption was obtained with the $40 \mathrm{kDa}$ PVDF membrane 850 L.h $\mathrm{h}^{-1} \cdot \mathrm{m}^{2}$ ). The PES 40, 100, PAN 40 and 50 membranes showed fluxes between 124 and $350 \mathrm{~L} . \mathrm{h}^{-1} \cdot \mathrm{m}^{2}$. The lowest fluxes were obtained with PES 3 and $10 \mathrm{kDa}$ (respectively 27 and $22 \mathrm{~L}^{\mathrm{h}} \mathrm{h}^{-1} \cdot \mathrm{m}^{2}$ ). The $10 \mathrm{kDa}$ RC membrane flux was about $50 \mathrm{~L} \cdot \mathrm{h}^{-1} \cdot \mathrm{m}^{2}$, showing an intermediate value compared to others.

After static contact with the washing water, the RC 70 PP membrane was the only one with a very low adsorption rate. The relative thickness of the adsorbed layer is about $0.4 \%$ while the thickness for other membranes was up to $25 \%$. Measured fluxes were noticeably less important after the $20 \mathrm{~h}$ contact. PVDF material seemed to possess the higher protein affinity. Indeed, the flux reduction was the highest using this material (from $850 \mathrm{~L} \cdot \mathrm{h}^{-1} \cdot \mathrm{m}^{2}$ to $28 \mathrm{~L} \cdot \mathrm{h}^{-1} \cdot \mathrm{m}^{2}$ ). PES material offered also a high protein affinity, noticed by a reduction of the permeate flux about 70 to $85 \%$ (corresponding to a pore size reduction ranging between 25 to $39 \%$ ). Results obtained with the PAN material membranes were quite similar than those obtained with the PES.

\section{Washing waters ultrafiltration}

Washing waters used (Aqueous fraction A2, Figure 2) were resulting from the washing of minced fish during the surimi manufacturing process.

In order to observe the influence of the material, ultrafiltration tests have been realized with 4 different membranes with identical MWCO (40 kDa) except for the RC membrane where only the 10 kDa MWCO was available.

\section{- Permeation flux measurements}

For each membrane, the permeation flux was measured every hour during 5 hours with a TMP of $1 \mathrm{bar}$, at $15^{\circ} \mathrm{C}$ in total recycling mode (Figure 4). The 4 curves possessed the same appearance: fluxes decreased during ultrafiltration time due to the accumulation of fouling substances (such as proteins or lipids) onto the membrane surface. However, there was a high flux difference between these materials. Permeate flux obtained for the PAN and PVDF membrane were quite similar (from 20 to $10 \mathrm{~L} \cdot \mathrm{h}^{-1} \cdot \mathrm{m}^{2}$ ). Permeate flux measured for the PES membrane was very low, around $1 \mathrm{~L} \cdot \mathrm{h}^{-1} \cdot \mathrm{m}^{2}$. Finally, the highest permeate flux is obtained with the RC membrane, during all the ultrafiltration process long (from the beginning of the process: $30 \mathrm{~L} \cdot \mathrm{h}^{-1} \cdot \mathrm{m}^{2}$ to the 5 hours of ultrafiltration: 20 L.h $\left.{ }^{1} . \mathrm{m}^{2}\right)$; corresponding to fluxes two times higher than those obtained with PVDF and PAN membranes.

At this step, it is interesting to notice that the membrane performance hierarchy in ultrafiltration mode was identical to that obtained during adsorption tests in static conditions: the membrane with the lower ratio $\Delta \mathrm{r} / \mathrm{r}$ is the most efficient in ultrafiltration and vice-versa. We can also notice than the material choice is important due to the different behaviour encountered at the same MWCO. On the basis of the experimental study, we could conclude that the most efficient membrane regarding the permeate flux is the $10 \mathrm{kDa} \mathrm{RC}$ membrane.

\section{- Membrane regenerability}

Another performance criterium in ultrafiltration field is the ability to recover the initial filtration characteristics of the membrane. For the PAN, PES and PDVF materials, a chemical cleaning process was realized after ultrafiltration (as indicated in the method part). The RC material has just been cleaned with a simple water rinsing. Pure water flux was measured before and after $5 \mathrm{~h}$ ultrafiltration of the water A2 in a concentration mode (Table 4). 
Comparing the water flux before ultrafiltration and after the cleaning process, the RC membrane was the only one to recover its initial reference flux. As a consequence, the regeneration of this material is much easier and the recovery of the performances will require negligible chemical cleaning reactants. Hence, this study confirms the precedent results: the material choice is as much important as the MWCO choice.

- Membrane selectivity, biochemical analyses

Biochemical analyses have been investigated on the washing waters A2 and every fraction generated after $5 \mathrm{~h}$ ultrafiltration (i.e on permeate and retentate). Concentration, lipids, proteins and ash contents are expressed in g.L-1. Results are given in Table 5.

Analysis of the PES ultrafiltration samples was not possible, due to the very low quantity of sample recovered with this low permeation flux $\left(\mathrm{J}<1\right.$ L.h. $\left.\mathrm{m}^{2}\right)$. Thus, this membrane was not further studied.

The mass conservation balance is given by:

$$
\mathrm{V}_{\mathrm{i} .} \mathrm{C}_{\mathrm{i}}=\mathrm{V}_{\mathrm{p}} \cdot \mathrm{C}_{\mathrm{p}}+\mathrm{V}_{\mathrm{r} .} \mathrm{C}_{\mathrm{r}}
$$

With $V_{i:}$ initial volume of A2 (L)

$\mathrm{C}_{\mathrm{i}}$ : initial concentration of solute in A2 (g. $\left.\mathrm{L}^{-1}\right)$

$\mathrm{V}_{\mathrm{p}}$ : volume of permeate $(\mathrm{L})$

$\mathrm{C}_{\mathrm{p}}$ : solute concentration in the permeate $\left(\mathrm{g} \cdot \mathrm{L}^{-1}\right)$

$\mathrm{V}_{\mathrm{r}}$ : volume of retentate $(\mathrm{L})$

Cr: solute concentration in the retentate (g.L-1)

The recovery rate (RR) (obtained after $5 \mathrm{~h}$ ultrafiltration) of compounds (lipids, proteins) is calculated according the following formula. Results are reported in Table 6.

$$
R R(\%)=\left[\left(\mathrm{V}_{\mathrm{i} .} \mathrm{C}_{\mathrm{i}}\right)-\left(\mathrm{V}_{\mathrm{p}} \cdot \mathrm{C}_{\mathrm{p}}\right)\right] /\left(\mathrm{V}_{\left.\mathrm{i} . \mathrm{C}_{\mathrm{i}}\right)} \cdot 100\right.
$$

Biochemical characterizations of the fractions generated during the ultrafiltration with the PAN, PVDF and RC membranes have shown that all of the membranes provided a high recovery rate of the lipids (96-98\%). A slight protein transmission is observed, but this transmission could easily be reduced with lower MWCO (e.g. $5 \mathrm{kDa}$ for RC material and $10 \mathrm{kDa}$ for PAN or PVDF materials).

\section{Membrane selection}

In this study, only one membrane was suitable according to the 3 performances criteria simultaneously: high performance flux, good selectivity and easy cleaning. This membrane is the RC $70 \mathrm{PP}$ membrane with a $10 \mathrm{kDa}$ MWCO. This membrane was thus selected to study the ultrafiltration in real conditions.

\section{Utilisation of RC 70 PP membrane}

The main goal was to confirm, in real ultrafiltration conditions (in concentration mode during a $8 \mathrm{~h}$ run), the performance ranges previously obtained (concerning the flux and the selectivity). The initial volume for the ultrafiltration was $2 \mathrm{~L}$.

The initial water flux Jo was $51.6 \mathrm{~L} \cdot \mathrm{h}^{-1} \cdot \mathrm{m}^{2}$. After $8 \mathrm{~h}$ ultrafiltration, the permeation flux was 16.7 L.h $\mathrm{h}^{-1} \cdot \mathrm{m}^{2}$ and the water flux after ultrafiltration and a rinsing step was $40.2 \mathrm{~L} \cdot \mathrm{h}^{-1} \cdot \mathrm{m}^{2}$. Figure 5 depicts the variation of the permeate flux according to running time. The volume reduction factor (VRF) is also reported on the graph and had been calculated following the formula: 
With $\mathrm{V}_{\mathrm{i}}$ initial A2 volume

$\mathrm{V}_{\mathrm{f}}$ final retentate volume

The ultrafiltration of the surimi wastewater A2 obtained with the RC membrane showed the same conclusions than those concerning the material selection. During the concentration, the permeate flux decreased due to the accumulation of matter at the membrane surface. However, the fouling layer was not strongly linked (low interactions) and a simple water rinse was sufficient to break and to eliminate this layer.

Obtained flux decreased from 30 to 17 L.h ${ }^{-1} \cdot \mathrm{m}^{-2}$ between the beginning of the concentration step and the end (where the volume reduction factor was 3.8). This ultrafiltration experiment has allowed to recover $0.53 \mathrm{~L}$ of fraction R2. Jaouen, with such a membrane material, had obtained on pouting (Trisopterus luscus) proteins flux ranged from 15 to $50 \mathrm{~L} \cdot \mathrm{h}^{-1} \cdot \mathrm{m}^{-2}$ (according to VRF) with a three times higher pressure [17]. So, values obtained here are ranged in the standard values generally founded at an industrial scale concerning protein ultrafiltration.

\section{Biochemical analysis of permeate and retentate obtained and selectivity}

The biochemical compositions of each fraction recovered after the ultrafiltration are reported in Table 7. The ultrafiltration of the surimi washing waters has allowed to concentrate the lipids and the proteins in the retentate fraction. Indeed, the initial contents of the A2 fraction were $0.8 \mathrm{~g} . \mathrm{L}^{-1} \mathrm{of}$ lipid and 34.6 g.L $\mathrm{L}^{-1}$ of protein. After conducing the ultrafiltration, lipid content in the retentate was 1.8 g.L.and the protein content was 62.5 g. $\mathrm{L}^{-1}$. Consequently, the permeate resulting from this ultrafiltration procedure possesses low lipid and protein contents (respectively 0.1 and $14.3 \mathrm{~g}^{\mathrm{L}} \mathrm{L}^{-1}$ ). Those results are correlated with the recovery rates obtained for lipids, around $90 \%$, and proteins, around $70 \%$. Similar results were found during the membrane selection step with slight variations (less than $10 \%$ ). The variations could be explained notably by variability of the raw material.

Hence the surimi washing waters A2 ultrafiltration using the RC 70 PP membrane seems to be effective for different reasons:

- the flux obtained is in the range of standard performances generally observed for such applications,

- the membrane possesses a good selectivity: the lipid retention is almost complete and few protein are passing through,

- the material used possesses a good regenerabilty and a low adsorption rate.

Moreover, the permeate recovered during this study possessed an odour similar to that of shrimp. An aromatic profile of this fraction could be investigated and could possess high interest. Indeed, it has been recently demonstrated that aroma compounds and marine flavours can be recovered using filtration techniques, such as nanofiltration [19] and electrodialysis [20].

Since lipids and the main protein fraction were recovered in the retentate, the polluting charge of effluent (permeate) was low. As described by Afonso and Bórquez, ultrafiltration reduces the organic load from the fish wastewaters and allows the recovery of valuable raw material comprising proteins [6]. The chemical oxygen demand (COD), one of the most important pollution indicators, was reduced by $75 \%$ during this treatment. This system may be further optimized by varying other parameters such as the pressure, tangential velocity and temperature parameters. 


\section{Sludge S1 hydrolysis}

The biochemical composition of the sludge S1 and of the resulting fractions of its hydrolysis, the aqueous fraction A3 and the sludge S3 are reported in Table 8.

After $2 \mathrm{~h}$ of hydrolysis $68 \%$ of the dry matter and proteins were solubilized and recovered in the fraction A3, indicating the effect of the papaïn on the sludge. Only $7 \%$ of the lipids were recovered into this fraction after proteolysis. The combination of hydrolysis with centrifugation allowed a high biochemical composition modification of samples and permitted to obtain on one hand a low fatty and rich proteinic fraction and on the other hand a lipid enriched sludge containing proteins. Further research should be done to analyze the appetence and digestibility on this resulting sludge to find a commercial application, such as in feed or pet-food.

\section{Aqueous fraction A3 ultrafiltration and concentration}

Around $960 \mathrm{~mL}$ of the aqueous fraction A3 were used to perform ultrafiltration using the RC 70 PP membrane as previously selected. The ultrafiltration was carried out for 2 hours at room temperature. During this experiment, the flux varied from 31.9 to $21.9 \mathrm{~L} . \mathrm{h}^{-1} \cdot \mathrm{m}^{2}$. At the end of the filtration, $520 \mathrm{~mL}$ of permeate (P3) and $440 \mathrm{~mL}$ of retentate (R3) were recovered, inducing a VRF around 2.2. The biochemical composition of each fraction is depicted in Table 9 . Around $83 \%$ of lipids and around $67 \%$ of the peptides present in the A3 fraction were retained by the membrane.

Thus, hydrolysis followed by centrifugation resulted in the modification of the biochemical composition of the S1 sludge, yielding a liquid (with proteins and few lipids) and an insoluble (containing fat and few proteins) fraction. Additional analyses concerning the taste and the digestibility and the sanitary state should indicate if this insoluble part could be used in feeding. Recovery rates obtained during the filtration of the soluble part were quite similar to those obtained during surimi wastewater S2 ultrafiltration on the same membrane. The hydrolysis of proteins with papain produced peptides, but the main part of the peptides generated is still retained by the membrane, despite their low molecular weight. The sludge, initially insoluble, has been mainly solubilized during hydrolysis, and, one more time, lipids and peptides have been concentrated.

\section{CONCLUSION}

Ultrafiltration, especially with a $10 \mathrm{kDa}$ regenerated cellulose membrane seems to be an appropriate technology for the recovery of proteins and lipids from sardine (Sardina pilchardus) surimi wastewater. Flux obtained is around $20 \mathrm{~L} / \mathrm{h} . \mathrm{m}^{2}$ with a recovery rate of $>70 \%$ for proteins and $>90 \%$ for lipids. The selected membrane possesses the same performances (selectivity, flux) in the filtration of the wastewater A2 or of the hydrolysate A3.

This preliminary step confirms that this kind of mild procedure is potentially interesting in the surimi effluent treatment. From highly charged effluents, it has been possible with centrifugation, controlled hydrolysis and membrane technology, to recover up-gradable substances (lipids, proteins), to suggest new ways of up-grading (aromatic compounds) and to decrease significantly the polluting load of the effluents generated, in this case, a reduction of COD by a factor of 4 . These results confirm those obtained previously by $\mathrm{Wu}$ et al. where COD decreased by $90 \%$ after nanofiltration treatment of surimi washing water [21] and those obtained by Mameri et al. where ultrafiltration reduced the biological oxygen demand after 5 days (BOD5) by about $80 \%$ for fishery washing water [22].

Such performances could likely be improved by optimizing the operating conditions (pressure, crossflow velocity, temperature, volume reduction factor), the membrane MWCO, or module 
configuration. Future work should focus on scaling-up, cleaning / regenerability and the energy consumption minimization.

\section{ACKNOWLEDGEMENT}

Authors also wish to thank to the Euro Seafood Trading Company (France) for providing PhD grant for this research. This work was performed within the Integrated Research Project SEAFOODplus, contract No FOOD-CT-2004-506359. The partial financing of the work by the European Union is gratefully acknowledged. This work was performed using the SiobioCle LIMS (Chatou, France).

\section{REFERENCES}

1. FAO fisheries department, The state of world fisheries and aquaculture. SOFIA, 144p (2004).

2. Eymard S., Carcouët E., Rochet M.J., Dumay J., Chopin C., Genot C., Development of lipid oxidation during manufacturing of horse mackerel surimi. J Sci. Food Agric. 85, 1750-1756 (2005).

3. Eymard S., Mise en évidence et suivi de l'oxydation des lipides au cours de la conservation et de la transformation du chinchard (Trachurus trachurus) : choix des procédés. Ph.D Thesis Nantes University, France, 143 pp (2003).

4. OFIMER, Les chiffres clés de la filière pêche et aquaculture en France. Office national interprofessionnel des produits de la mer et de l'aquaculture, rapport d'activité. 86 pp (2006).

5. Dumay J., Extraction de lipides en voie aqueuse par bioréacteur enzymatique combiné à l'ultrafiltration: application à la valorisation de co-produits de poissons (Sardina pilchardus). Ph.D Thesis, Nantes University, France, 306 pp (2006).

6. Afonso, M.D., Borquez, R., Review of the treatment of seafood processing wastewaters and recovery of proteins therein by membrane separation processes- prospects of the ultrafiltration of wastewaters from the fish meal industry. Desalination, 142, 29-45 (2002).

7. Lin T.M., Park J.W., Morrissey M.T., Recovered protein and reconditioned water from surimi processing waste. J. Food Sci. 60, 4-9 (1995).

8. Afonso, M.D., Borquez, R., Nanofiltration of wastewaters from the fish meal industry. Desalination, 151, 131-138 (2002).

9. Mireles DeWitt C.A., Morrissey M.T., Parameters for the recovery of proteases from surimi wash water. Biores. Technol. 82, 295-301 (2002).

10. Mireles DeWitt C.A., Morrissey M.T., Pilot plant recovery of catheptic proteases from surimi wash water. Biores. Technol. 81, 241-247 (2002).

11. Dumay J., Barthomeuf C., Bergé J.P., How enzymes may be helpful for upgrading fish byproducts: enhancement of fat extraction. J. Aquacultural Food Product Technol., 13, 69-84 (2004).

12. Dumay J., Donnay-Moreno C., Barnathan, G., Jaouen P., Bergé, J.P., Improvement of lipid and phospholipid recoveries from sardine (Sardina pilchardus) viscera using industrial proteases. Process Biochem., 41, 2327-2332 (2006).

13. Jaouen P. and Quéméneur F., Membrane filtration for waste protein recovery. In: Fish Processing Technology. Hall, G.M. (Ed), Chapman \& Hall, Blackie and Son Limited, Glasgow, pp. 212-248 (1992).

14. Huang L., Morrissey M.T., Fouling of membranes during microfiltration of surimi wash water : roles of pore blocking and surface cake formation. J. Memb. Sci. 144, 113-123 (1998).

15. Folch J., Lees M., Sloan-Stanley G.H., A simple method for the isolation and purification of total lipids from animal tissues. J. Biol. Chem. 226, 497-509 (1957). 
16. Crooke, W. M., Simpson, W. E., Determination of ammonium in Kjeldhal digests of crops by an automated procedure. J. Agric. Food Chem., 27, 1256-1262 (1971).

17. Jaouen P., Etude des techniques de séparation par membrane dans le domaine des pêches et des cultures marines: récupération de protéines solubles de poisson par ultrafiltration; concentration de micro-algues marines par microfiltration tangentielle. Ph.D Thesis Nantes University - Ecole centrale, France, 269 pp (1989).

18. Zeman L.J., Adsorption effects in rejection of macromolecules by ultrafiltration membranes. J. Memb. Sci. 15, 213-230 (1983).

19. Vandanjon L., Cros S., Jaouen P., Quéméneur F., Bourseau P., Recovery by nanofiltration and reverse osmosis of marine flavours from seafood cooking waters. Desalination, 144, 379-385 (2002).

20. Cros S., Lignot B., Razafintinsalama C., Jaouen P., Bourseau P., Electrodialysis desalination and reverse osmosis concentration of an industrial mussel cooking juice: process impact on pollution reduction and on aroma quality. J. Food Sci., 69, 435-442, (2004).

21. Wu T.Y., Mohammad A.W., Anuar N., Rahman R.A., Potential use of nanofiltration membrane in treatment of wastewater from fish and surimi industries. Songklanakarin J. Sci. Technol. 24, 977987 (2002).

22. Mameri N., Abdessemed D., Belhocine D., Lounici H., Treatment of fishery washing water by ultrafiltration. J. Chem. Tech. Biotechnol. 67, 169-175 (1996). 
Table 1 : Pilot Rayflow ${ }^{\circledR} 100$ characteristics (manufacturer data)

\begin{tabular}{ll}
\hline Membrane surface & $100 \mathrm{~cm}^{2}$ \\
\hline Pressure range & 0 to 3 bars \\
\hline Circulation flux & 0 to $700 \mathrm{~L} / \mathrm{h}$ \\
\hline Liquid vein thickness & 0,5 to $1,5 \mathrm{~mm}$ \\
\hline Mean linear speed & $\begin{array}{l}1.7 \mathrm{~m} / \mathrm{s} \text { for } 250 \mathrm{~L} / \mathrm{h} \text { and } 0.5 \mathrm{~mm} \text { joint } \\
(\text { Reynolds }=1700)\end{array}$ \\
\hline Maximal working temperature & $50^{\circ} \mathrm{C}\left(20^{\circ} \mathrm{C}\right.$ at 4 bars $)$ \\
\hline Cleaning temperature & $121^{\circ} \mathrm{C}$ \\
\hline Module internal volume : & \\
Retentate part & $22 \mathrm{~mL}$ \\
Permeate part & $8 \mathrm{~mL}$
\end{tabular}

Table 2 : Membranes characteristics (manufacturer data)

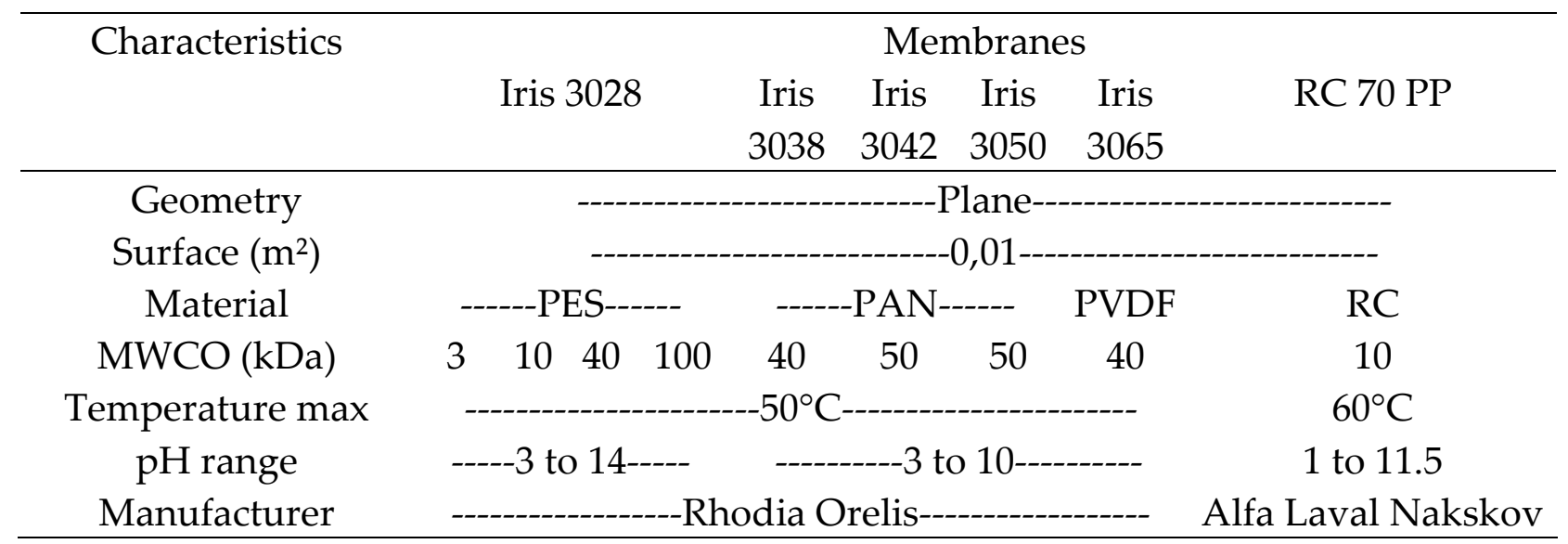

PES : PolyEther Sulfone. - PAN : PolyAcrylonitrile, the 3042 membrane is anionic while the 3050 membrane is cationic - PVDF : PolyVinyliDeneFluoride - RC : Regenerated cellulose 
Table 3 : Membrane water flux before and after $20 \mathrm{~h}$ long static contact with washing waters A2 and pore size reduction with the PES, PAN, PVDF and RC membrane materials

\begin{tabular}{|c|c|c|c|c|}
\hline \multicolumn{2}{|c|}{ Membrane } & \multirow{2}{*}{$\begin{array}{c}\text { Jo water flux } \\
\left(\mathrm{L} \cdot \mathrm{h}^{-1} \cdot \mathrm{m}^{2}\right) \\
{ }^{\circ} \mathrm{C}=15^{\circ} \mathrm{C}, \Delta \mathrm{P}=1 \mathrm{bar}\end{array}$} & \multirow{2}{*}{$\begin{array}{c}\mathrm{Ja}_{\mathrm{a}} \text { water flux after } \\
\text { adsorption }\left(\mathrm{L} \cdot \mathrm{h}^{-1} \cdot \mathrm{m}^{2}\right) \\
\mathrm{T}^{\circ} \mathrm{C}=15^{\circ} \mathrm{C}, \Delta \mathrm{P}=1 \mathrm{bar}\end{array}$} & \multirow{2}{*}{$\begin{array}{l}\text { Pore size reduction } \\
\Delta \mathrm{r} / \mathrm{r}(\%)=1-\left(\mathrm{J}_{\mathrm{a}} / \mathrm{J}_{\mathrm{o}}\right)^{0.25}\end{array}$} \\
\hline Type & $\mathrm{kDa}$ & & & \\
\hline \multirow{4}{*}{ PES 3028} & 3 & 27.0 & 4.0 & $39.0 \%$ \\
\hline & 10 & 22.0 & 7.0 & $25.0 \%$ \\
\hline & 40 & 179.0 & 42.0 & $30.0 \%$ \\
\hline & 100 & 124.0 & 20.0 & $36.0 \%$ \\
\hline PAN 3038 & 40 & 142.0 & 24.0 & $36.0 \%$ \\
\hline PAN 3042 & 50 & 222.0 & 36.0 & $37.0 \%$ \\
\hline PAN 3050 & 50 & 350.0 & 34.0 & $44.0 \%$ \\
\hline PVDF 3065 & 40 & 850.0 & 28.0 & $57.0 \%$ \\
\hline RC 70 PP & 10 & 50.6 & 50.0 & $0.4 \%$ \\
\hline
\end{tabular}

Table 4: Permeate flux before and after ultrafiltration of the aqueous fraction A2 with the PES, PAN, PVDF and RC membrane materials

\begin{tabular}{lccc}
\hline Membrane & $\begin{array}{c}\text { Water flux before } \\
\text { ultrafiltration }\left(\mathrm{L} \cdot \mathrm{h}^{-1} \cdot \mathrm{m}^{2}\right)\end{array}$ & $\begin{array}{c}\text { Flux after } 5 \text { hours } \\
\text { with A2 }\left(\mathrm{L} \cdot \mathrm{h}^{-1} \cdot \mathrm{m}^{2}\right)\end{array}$ & $\begin{array}{c}\text { Water flux after } \\
\text { cleaning }\left(\mathrm{L} \cdot \mathrm{h}^{-1} \cdot \mathrm{m}^{2}\right)\end{array}$ \\
\hline PES 40 kDa & 179 & $<1$ & 1.2 \\
PAN 40 kDa & 142 & 12 & 30 \\
PVDF 40 kDa & 850 & 11.5 & 29 \\
RC 10 kDa & 50.6 & 20 & 49.3 \\
\hline
\end{tabular}

Table 5 : Biochemical composition (dry matter, lipids, proteins) of fractions obtained after $\mathrm{A} 2$ ultrafiltration. $\mathrm{T}=15^{\circ} \mathrm{C}, \mathrm{PTM}=1$ bar.

\begin{tabular}{lccc}
\hline Samples & Dry matter $\left(\mathrm{g} . \mathrm{L}^{-1}\right)$ & Lipids $\left(\mathrm{g} . \mathrm{L}^{-1}\right)$ & Proteins $\left(\mathrm{g} . \mathrm{L}^{-1}\right)$ \\
\hline A2 fraction & 37.5 & $1.8 \pm 0.5$ & $26.5 \pm 0.7$ \\
PAN retentate & 59.0 & $2.3 \pm 0.7$ & $48.3 \pm 0.8$ \\
PAN permeate & 21.1 & $0.1 \pm 0.0$ & $10.6 \pm 0.2$ \\
PVDF retentate & 59.0 & $2.7 \pm 1.1$ & $49.2 \pm 1.2$ \\
PVDF permeate & 16.9 & $0.1 \pm 0.0$ & $9.3 \pm 0.3$ \\
CR retentate & 69.1 & $0.8 \pm 0.2$ & $60.4 \pm 1.4$ \\
CR permeate & 14.8 & $0.1 \pm 0.0$ & $9.2 \pm 0.2$ \\
\hline
\end{tabular}


Table 6 : Lipids and proteins Recovery rates (RR) obtained after ultrafiltration of the washing waters A2 with the PAN, PVDF and RC membranes

\begin{tabular}{c|cc}
\hline & Lipids RR (\%) & Proteins RR (\%) \\
\hline PAN & 96.4 & 78.9 \\
PVDF & 97.4 & 79.8 \\
RC & 98.0 & 79.9 \\
\hline
\end{tabular}

Table 7 : Biochemical analyses (g.L $\mathrm{L}^{-1}$ ) (dry matter, lipids and proteins) performed on each fraction (retentate and permeate) of the washing waters A2 ultrafiltration with the $10 \mathrm{kDa} R \mathrm{R}$ membrane and obtained recovery rates $\left(\mathrm{T}=15^{\circ} \mathrm{C}, \mathrm{TPM}=1 \mathrm{bar}, \mathrm{VRF}=\right.$ 3.8)

\begin{tabular}{cccc}
\hline Samples & DM & Lipids & Proteins \\
\hline A2 & 49.3 & $0.8 \pm 0.0$ & $34.6 \pm 1.7$ \\
R2 & 74.2 & $1.8 \pm 0.1$ & $62.5 \pm 0.2$ \\
P2 & 24.6 & $0.1 \pm 0.0$ & $14.3 \pm 0.5$ \\
\hline RR (\%) & - & 89.8 & 69.7 \\
\hline
\end{tabular}

Table 8 : Biochemical composition before and after hydrolysis of the sludge S1 (g/100 g samples)

\begin{tabular}{cccc}
\hline Samples & DM & Lipids & Peptides \\
\hline S1 & 21.99 & $1.43 \pm 0.1$ & $19.21 \pm 0.4$ \\
A3 & 9.84 & $0.07 \pm 0.0$ & $7.22 \pm 0.2$ \\
S3 & 21.03 & $3.60 \pm 0.2$ & $15.39 \pm 0.1$ \\
\hline
\end{tabular}

Table 9: Biochemical composition after ultrafiltration of the aqueous fraction A3, resulting from the enzymatic hydrolysis of the sludge $\mathrm{S} 1$ (g/100 g sample)

\begin{tabular}{cccc}
\hline Samples & DM & Lipids & Peptides \\
\hline A3 & 9.84 & $0.07 \pm 0.0$ & $7.22 \pm 0.2$ \\
R3 & 7.65 & $0.06 \pm 0.0$ & $6.29 \pm 0.0$ \\
P3 & 7.82 & $0.02 \pm 0.0$ & $4.43 \pm 0.2$ \\
\hline
\end{tabular}




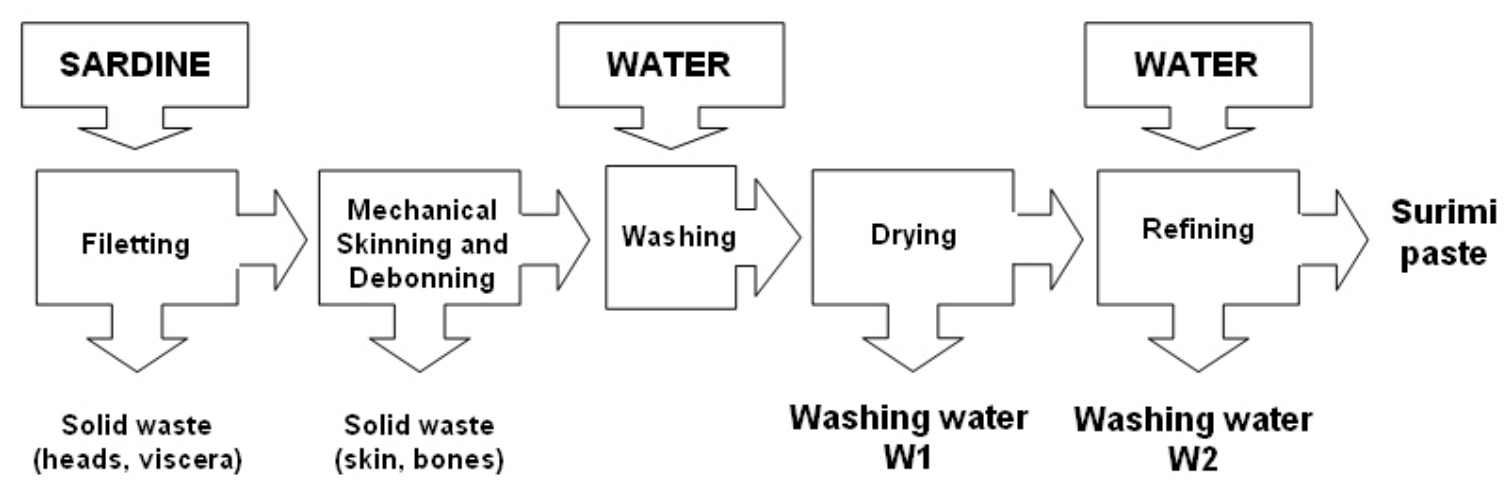

Figure 1: Schematic representation of the pilot line for surimi manufacturing

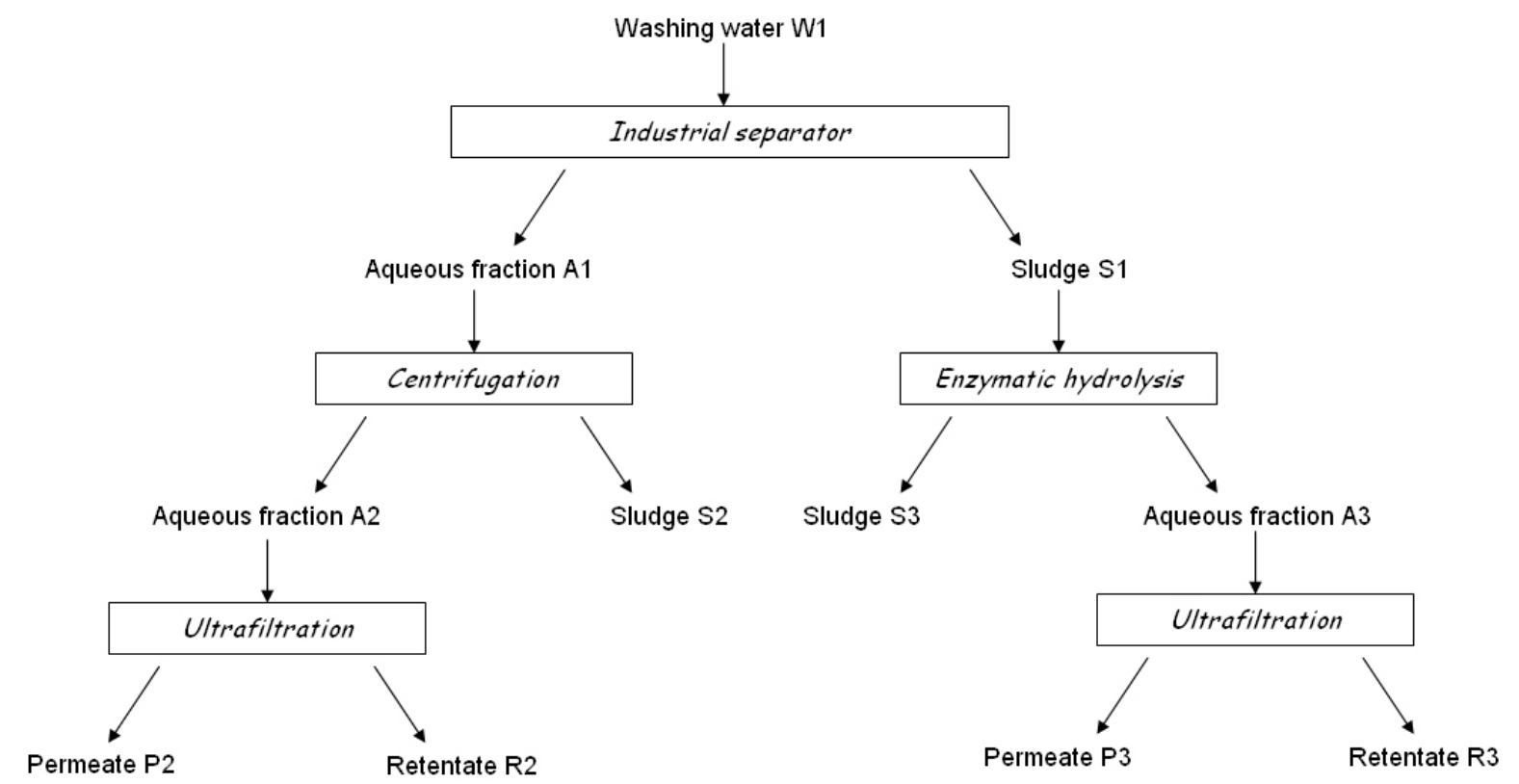

Figure 2 : Scheme for washing waters treatment 

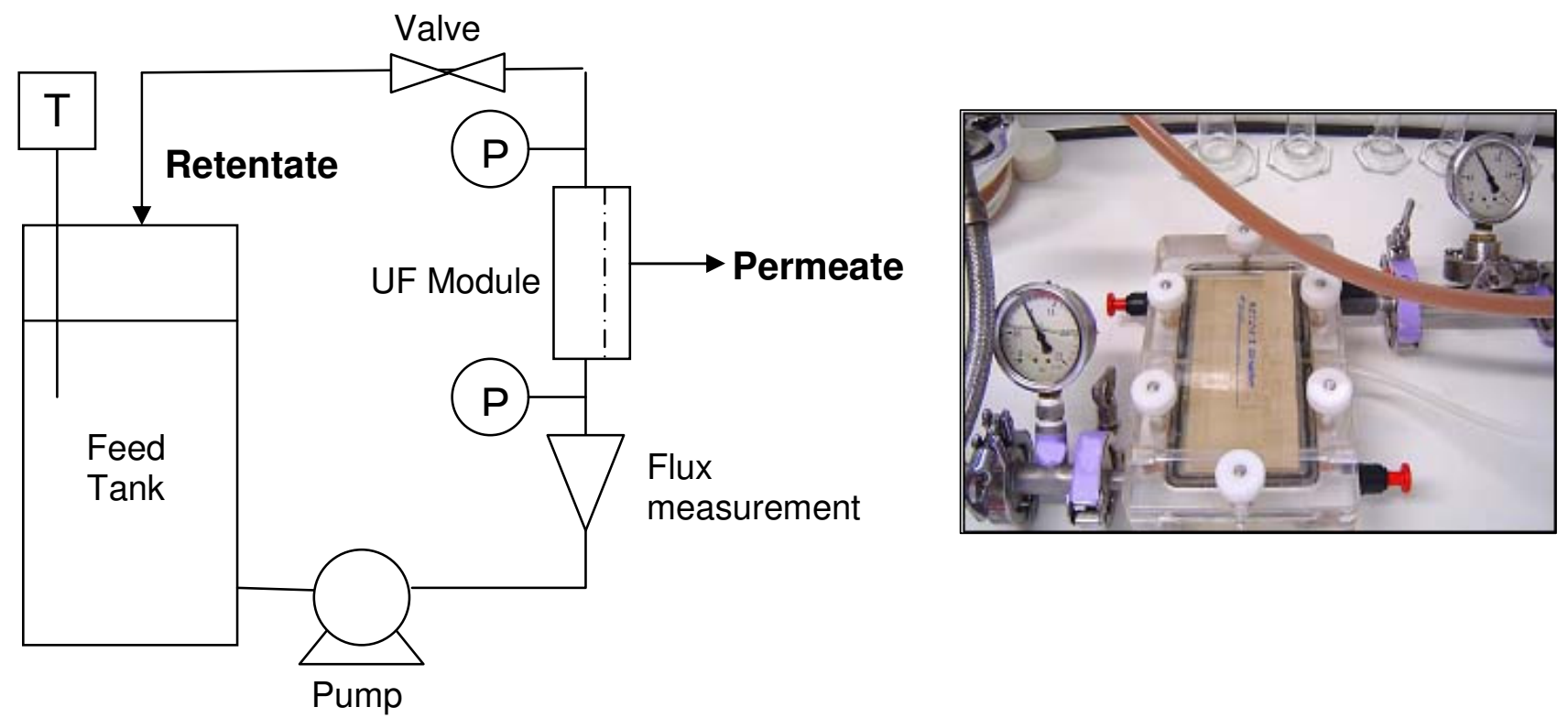

Figure 3: Ultrafiltration pilot representation. T: temperature measurement. P : pressure measurement 


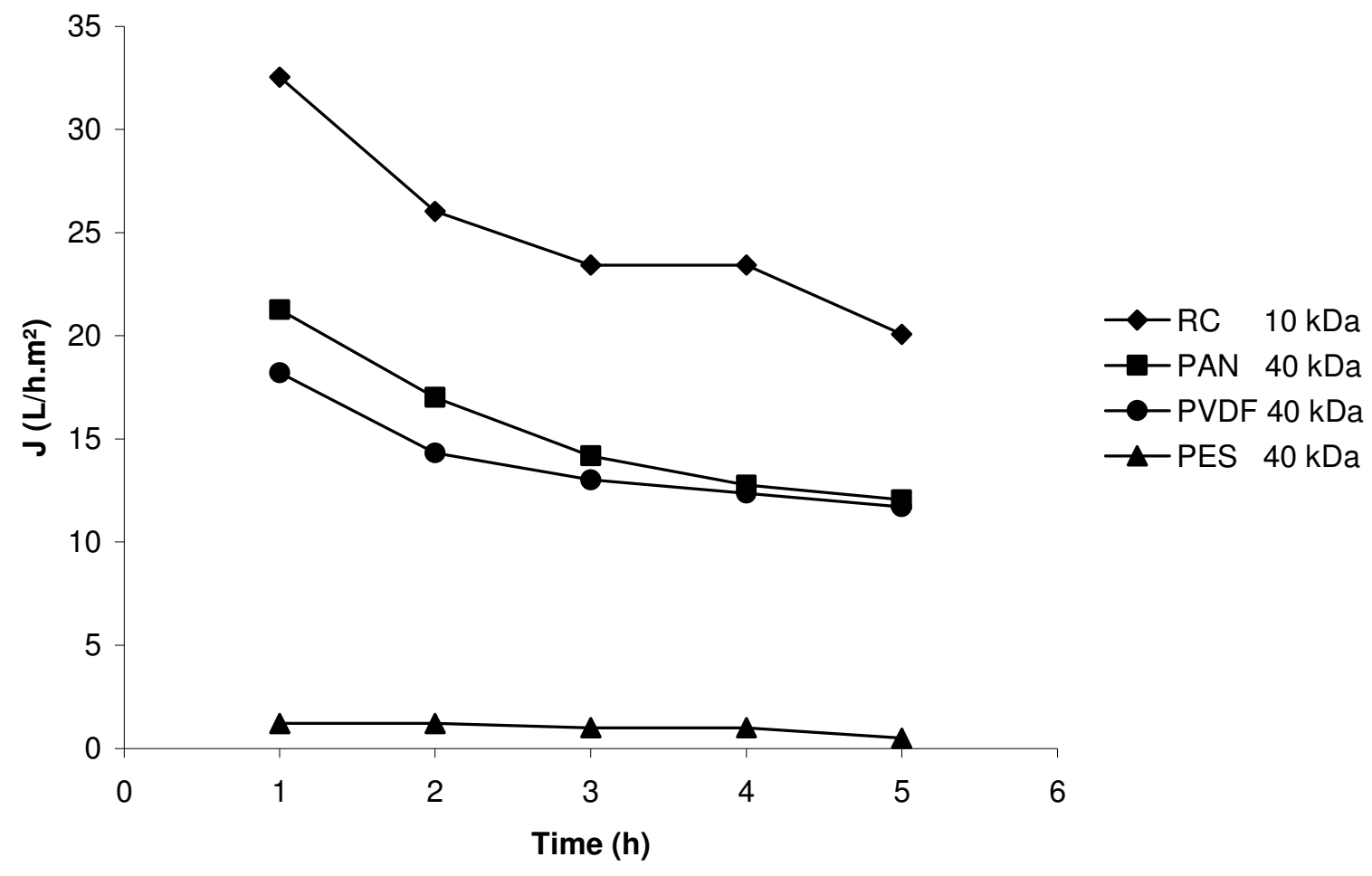

Figure 4 : Permeation flux variation for each material during A2 ultrafiltration 


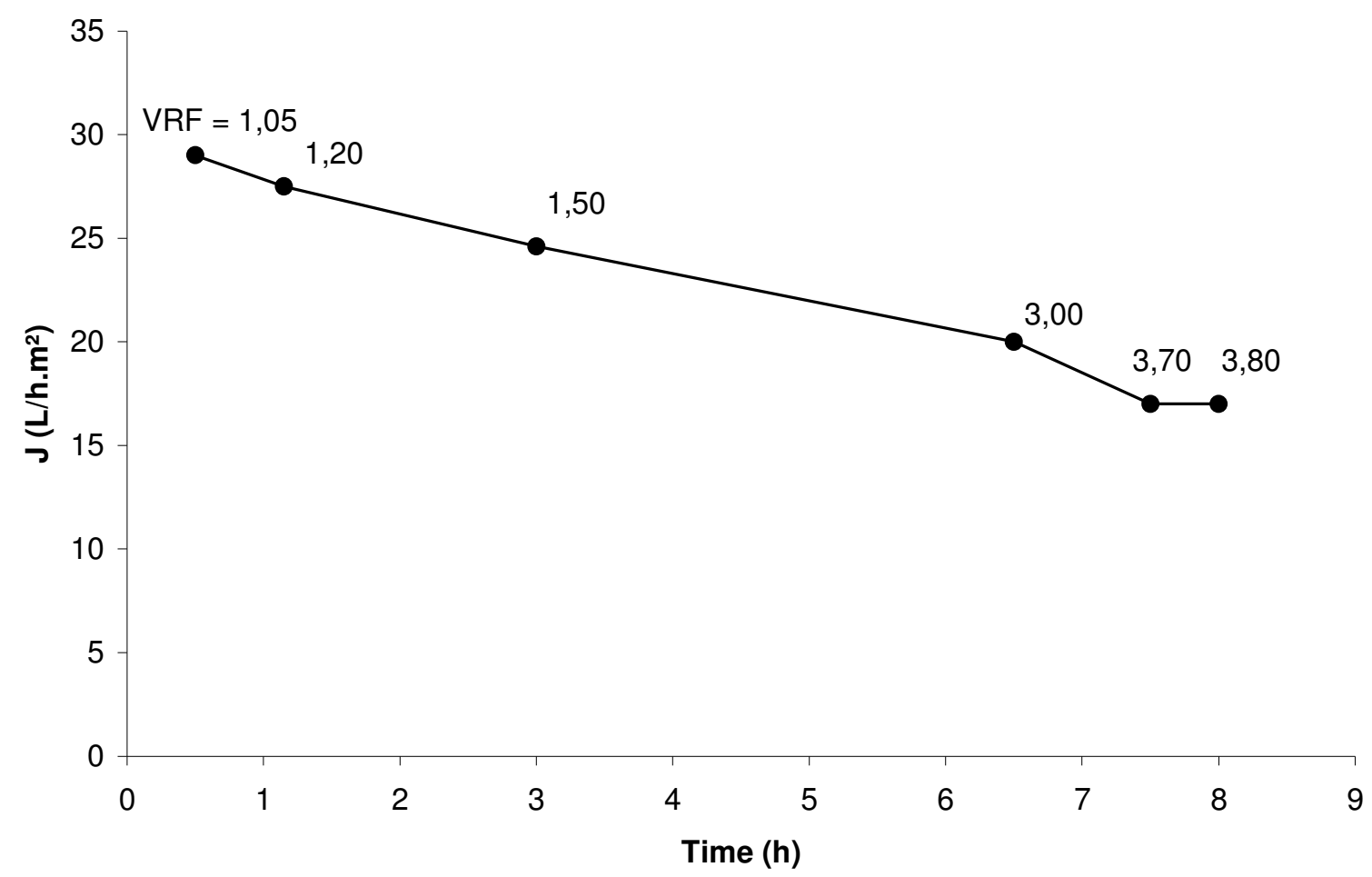

Figure 5 : Permeate flux variation and Volume Reduction Factor (VRF) in concentration mode during A2 ultrafiltration with RC 70 PP membrane 